SINAI Journal of Applied Sciences 10 (2) 2021 121-136

$\begin{array}{ccc}\text { Available online at www.sinjas.journals.ekb.eg } & \overline{\text { ARU-EGYPT }} \\ \text { SCREENED BY SINAI Journal of Applied Sciences }\end{array}$

\title{
IMPACT OF GLYCOMACROPEPTIDE AND CRUDE VIRGIN OLIVE OIL ON PROPERTIES OF BIO-YOGHURT
}

\author{
Ola F. El-Sayed ${ }^{* 1}$, H.A. El-Shazly ${ }^{2}$, H.A. El-Demerdash ${ }^{1}$, M.M.K. Metwally ${ }^{1}$ \\ 1. Dept. Dairy and Food Sci., Fac. Environ. Agric. Sci., Arish Univ., Egypt. \\ 2. Dept. Dairy Sci., Food Technol. Res. Inst., Ministry Agric. and Land Reclamation, Egypt.
}

\begin{tabular}{l} 
ARTICLE INFO \\
\hline Article history: \\
Received: $20 / 06 / 2021$ \\
Revised: $28 / 08 / 2021$ \\
Accepted: 28/08/2021 \\
Available online: $28 / 08 / 2021$ \\
\hline Keywords: \\
Yoghurt, B. bifidum, \\
GMP, \\
olive oil
\end{tabular}

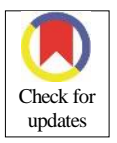

\begin{abstract}
In this study, bio-yoghurt was manufactured using cow milk and addition of $1 \%$ Bifidobacterium bifidum Bb12 to yoghurt culture consist of $2 \%$ (Streptococcus thermophilus and Lactobacillus delbrueckii subsp. bulgaricus) (1:1) The study also concerned with improving the viability of the used bacteria by adding $0.01 \%$ glycomacropeptide (GMP) and $0.1 \%$ crude virgin olive oil (CVOO) to milk prepared for yoghurt industry. The effect of these additions on microbiological, chemical, rheological and sensory properties has been studied of the final product during storage period for 21 days at $5^{\circ} \mathrm{C}$. The results revealed that, numbers of bacteria Lb. bulgaricus, $S$. thermophiles, B. bifidum and total bacterial count were increased in treated yoghurt more than control during storage period. Yeasts and moulds were appeared in yoghurt fortified with $0.01 \%$ GMP and control after 15 days of storage. All yoghurt treatments as well as control were completely free from coliform group during storage period. Values of $\mathrm{pH}$ for all yoghurt samples, decreased generally while the content (\%) of acidity, total solid (TS), Total protein (TP), water soluble nitrogen (WSN) and fat increased during progress of storage period and all treatments have values more than control. Syneresis decreased during progress of storage period. Hardness, Cohesiveness, Gumminess and Chewiness increased for all treatments during storage while Springiness decreased for all treatments during storage period. Yoghurt fortified with GMP (T1) had the highest total acceptance during storage for 21 days at $5^{\circ} \mathrm{C}$.
\end{abstract}

\section{INTRODUCTION}

Yoghurt is a coagulated dairy product produced by fermentation of milk with bacterial cultures consisting of a mixture of Streptococcus thermophilus and Lactobacillus delbrueckii subsp. bulgaricus (Gundogdu et al., 2009). Addition of these cultures results in acidification of milk and synthesis of aromatic compounds (Sahan et al., 2008; Sera et al., 2009). These microflorae have been found to be valuable for human as they help in maintaining health and nutrition. Efforts have been focused on developing yoghurt containing probiotic cultures like Lactobacillus acidophilus and Bifidobacterium bifidum (Vinderola and
Reinheimer, 2000).Probiotic cultures are live microorganisms in human intestinal that are beneficial for human health and improve the intestinal microbial balance resulting in the inhibition of bacterial pathogens, reducing the risk of colon cancer, improving the immune system, lowering serum cholesterol levels (Saarela $\boldsymbol{e t}$ al., 2002) and alleviation of lactose intolerance and nutritional enhancement (Alizadeh and Ehsani, 2008).

Glycomacropeptide (GMP), arising from cleavage of $\kappa$-casein by chymosin or pepsin (Farrell et al., 2004), exhibits several useful biological activities, including binding of cholera toxin and E. coli enterotoxins, inhibition of bacterial and viral adhesions,

\footnotetext{
* Corresponding author: E-mail address: ommoaaz50@gmail.com https://doi.org/10.21608/sinjas.2021.80079.1026

(C) 2021 SINAI Journal of Applied Sciences. Published by Fac. Environ. Agric. Sci., Arish Univ. All rights reserved.
} 
suppression of gastric secretions, promotion of bifidobacterial growth, and modulation of immune responses (Brody, 2000). GMP don't contains aromatic amino acids, therefore it used for phenylketonuria (PKU) diets (Ney et al., 2009). It is growing interest in exploiting GMP for use in food industry, GMP provides good palatability and functional properties imparting favorable mouthfeel and flavour to foods, which many existing food preparations used for PKU diets lack (Marshall, 2004).

Olive (Olea europea L.) is an evergreen tree that has been traditionally cultivated for olive oil and table consumption. Olive oil is classified as virgin olive oil if it has been extracted exclusively by mechanical or physical procedures such as milling, beating, centrifugation and decantation (Gandul-Rojas et al., 2000). The importance of virgin olive oil is related to its high levels of mono-unsaturated fatty acids (mainly oleic acid) and to the presence of minor components including aliphatic and tri-terpenic alcohols, sterols, hydrocarbons, volatile compounds and several antioxidants (Ocakoglu et al., 2009). Olive oil rich diet protects human health from cardiovascular diseases, hypertention, inflammation, oxidative stress, obesity, type-2 diabetes and cancer (Wani et al., 2018).

The aim of this study was to evaluate the influence of glycomacropeptide and crude virgin olive oil to yoghurt on the viability of lactic acid bacteria (LAB) and probiotic cultures as well as chemical, rheological and organoleptic properties of fresh yoghurt and during storage for 21 days at $5^{\circ} \mathrm{C}$.

\section{MATERIALS AND METHODS}

\section{Materials}

Fresh cow's milk was obtained from the herd of Badwy farm of Arish, Egypt. Average chemical composition of milk (3.5\% fat, $3.35 \%$ protein, $12.6 \% \mathrm{TS})$ were determined according to the methods described in AOAC (2016).
Skim milk powder $(96 \%$ TS, product of Dairy America $^{\mathrm{TM}}$ ) USA, was obtained from the local market of Arish, Egypt.

Direct Vat Starter (DVS) of yoghurt culture was obtained from CHR-Hansen's laboratorie, Denmark, under commercial name type (FD-DVS-YC-X11) containing Streptococcus thermophiles and Lactobacillus delbrueckii ssp. bulgaricus.

Probiotic bacteria strain Bifidobacterium bifidum Bb12 was obtained from bafm, Germany.

Glycomacropeptide (GMP) was obtained from Ajinomoto Co., Inc., Tokyo, Japan.

Crude virgin olive oil (CVOO) (Olea europea L.) was obtained from Badawy olive press of Arish, Egypt.

\section{Methods}

\section{Preparation of probiotic culture}

Strains of Bifidobacterium bifidum was twice successively activated by inoculating $100 \mathrm{ul}$ of organism in $10 \mathrm{ml}$ of sterilized MRS broth and incubated at $37^{\circ} \mathrm{C}$ for 16 hours. $10 \mathrm{ml}$ of inoculated MRS broth was added to $100 \mathrm{ml}$ of skim milk $(9 \%)$ and incubated at $37^{\circ} \mathrm{C}$ overnight, then stored at $5^{\circ} \mathrm{C}$ until used according to De Man et al. (1960).

Yoghurt was manufactured from standardized cow's milk according to Tamime and Robinson (1999). Three treatments of yoghurt were prepared as follows:

\section{Treatment 0 (T0)}

Yoghurt without any additives which serves as a control is shown in (Diagram A).

\section{Treatment 1 (T1)}

Yoghurt with $0.01 \%$ GMP was used in manufacture of yoghurt according to the procedure mentioned by Tain $\boldsymbol{e t}$ al. (2015) is shown in Diagram A.

Treatment 2 (T2) Yoghurt with $0.1 \%$ crude virgin olive oil was used in the manufacture of yoghurt according to the procedure mentioned by Abbas et al. (2015) is shown in Diagram A. 
Diagram (A) - Manufacture of yoghurt

Fresh cow's milk (3.5\% fat, $3.35 \%$ protein, $12.6 \%$ TS)
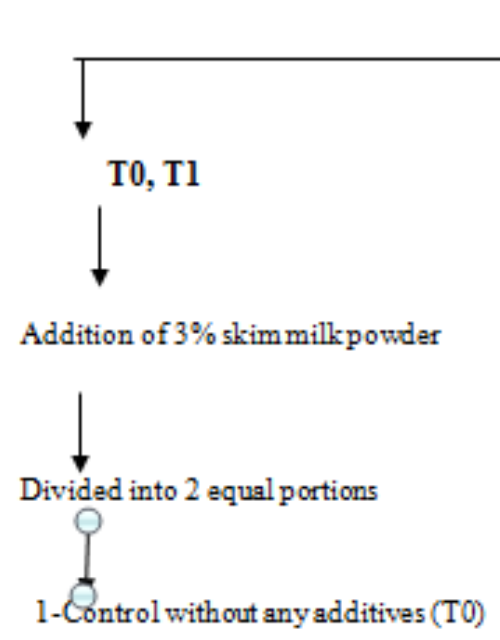

Addition of

$2-0.01 \% \mathrm{GMP}(\mathrm{T} 1)$

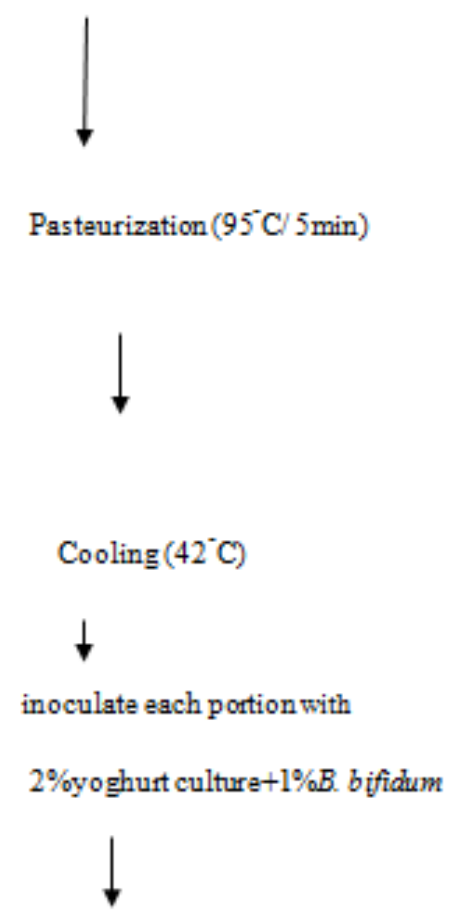

Filled into plastic containe

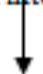

Incubation at $42^{\circ} \mathrm{C}$ until complete cosgulation

Storage in refrigerator at $5^{-}$for 21 days
Addition 3\% skimmilkpowder

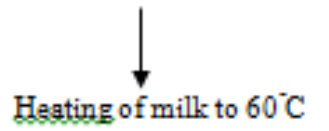

Additon $\downarrow_{\mathrm{f} 0.1 \% \mathrm{CV} O 0}$

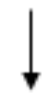

Mixing the mixture in a blender $3 \mathrm{~min}$

Reheating of mix. for Pasteurization

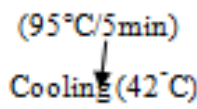

ineculation with $2 \%$ yoghurt culture $+1 \%$ B. bfidum

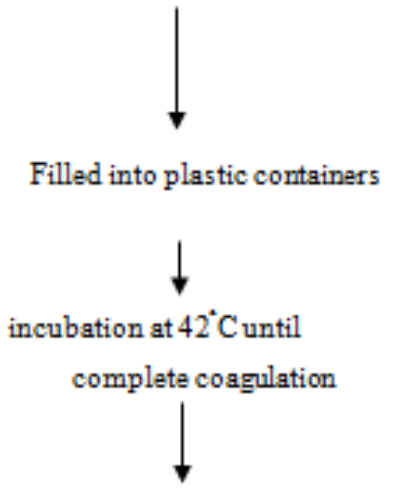

Storage in refrigerator at $5^{\circ} \mathrm{C}$ for 21 days 
Analysis of yoghurt

Yoghurt samples were analyzed microbiologically, chemically, rheiologically and organolepically at zero time, 3, 7, 15 and 21 days of storage at $5^{\circ} \mathrm{C}$.

\section{Microbiological Analyses}

Preparation of all samples for microbiological examination was carried out as described by Frazier and Foster (1961).

Total bacterial counts were determined by the general plate count technique as described by Marshall (1992).

Lb. delbrueckii ssp. bulgaricus were determined using MRS agar medium Dave and Shah, (1996). Colonies were counted after anaerobic incubation using a double layer of medium. Plates were incubated at $43^{\circ} \mathrm{C}$ for $48 \mathrm{hr}$.

$S$. thermophiles were determined by using M17 selective medium as described by Krusch et al. (1987). Plates were aerobically incubated at $43^{\circ} \mathrm{C}$ for $48 \mathrm{hr}$.

$B$. bifidum were determined by using MRS agar medium (Oxoid) supplemented with $0.05 \%$ L-cystein and $0.3 \%$ lithium chloride. Plates were incubated at $37^{\circ} \mathrm{C}$ for $48 \mathrm{hr}$. under anaerobic conditions according to Dave and Shah (1996).

Moulds and Yeasts were determined on oxytetracycline glucose yeast extract agar medium as suggested by Harrigan and Mcconce (1966). Plates were incubated at $25^{\circ} \mathrm{C}$ for 3 days.

Coliform groups were determined according to the American Public Health Association (1992). Appropriate dilutions of samples were plated on Mac Conk's agar medium and incubated at $37^{\circ} \mathrm{C}$ for $48 \mathrm{hr}$.

\section{Chemical Analyses}

$\mathrm{pH}$ values were measured using Jenway $\mathrm{pH}$ meter with Jenway spear electrode No: 29010 (Jenway limited Gransmore Green, Felsted, Dunmow, England).
Titratable acidity, total solids, total protein, water soluble nitrogen and fat were determined according to the method described by AOAC (2016).

Syneresis was determined by measuring the volume of separated whey ( $\mathrm{ml}$ whey/ 50 $\mathrm{ml}$ yoghurt) collected after $30 \mathrm{~min}$ at room temperature according to Abd El-Salam $\boldsymbol{e t}$ al. (1991).

\section{Rheological Properties}

\section{Texture profile analyses (TPA)}

Performed of yoghurt samples was done using a Universal Testing Machine (TMSPro) equipped with (250 lbf) load cell and connected to a computer programmed with Texture Pro $^{\mathrm{TM}}$ texture analysis software (program, DEV TPA withhold). A flat rod probe (49.95 $\mathrm{mm}$ in diameter) was used to uniaxial compress the yoghurt samples to $50 \%$ of their original height. The texture profile analysis test set condition was adjusted to a test speed $60 \mathrm{~mm} / \mathrm{sec}$; trigger force $1 \mathrm{~N}$, deformation $25 \%$ and holding time 2 seconds between cycles. The texture of yoghurt samples was evaluated at the temperature being $5^{\circ} \mathrm{C}$ and $-18^{\circ} \mathrm{C}$, respectively. Each sample was subjected to two subsequent cycles (bites) of compression-decompression. The following parameters were evaluated by TPA according to the definitions by International Dairy Federation (1991)

\section{Hardness}

Force necessary to attain a given deformation.

\section{Cohesiveness}

The extents to which a material can be deformed before it ruptures.

\section{Springiness}

In the rate which the sample returns to its original shape when the deforming force is removed.

\section{Gumminess}

Force needed to disintegrate the sample to a state ready for swallowing. 


\section{Chewiness}

Work needed to masticate the sample to state ready for swallowing.

\section{Organoleptic Properties}

Organoleptic properties of yoghurt samples were evaluated according to Tamime and Robinson (1999). Yoghurt was examined for flavour (0-10 points), body and texture ( 0 - 5 points) and appearance and color (0 -5 points).

\section{Statistical Analysis}

The statistical analysis was carried out using one-way analysis of variance (ANOVA) under significant level of 0.05 for the whole results using the statistical program Costas (Ver. 6.400), data were expressed as mean \pm stander error (SE) with complete randomization design according to Steel et al. (1997). To ascertain the significant among means of different samples, least significant difference (LSD) test was applied.

\section{RESULTS AND DISCUSSION}

\section{Microbiological Analysis}

Table 1 illustrate all microbiological analysis applied for yoghurt fortified with GMP and CVOO including viable counts $\log 10(\mathrm{cfu} / \mathrm{ml})$ of yoghurt starters $L b$. bulgaricus, $S$. thermophilus, B. bifidum and total bacteria during storage at $5^{\circ} \mathrm{C}$ for 21 days. In general, there was a significant difference $(\mathrm{p}<0.05)$ in counts of $L b$. bulgaricus, $S$. thermophilus, B. bifidum and total bacteria between control and yoghurt treatments at zero time and the end of storage period. Results indicated that the numbers of previous bacteria increased until 15 days of storage, then decreased at the end of storage period. the highest values obtained in yoghurt fortified with $0.01 \%$ GMP followed by yoghurt fortified with $0.1 \%$ CVOO. There were no significant differences $(p<0.05)$ among treated yoghurts at zero time, 3, 7 and 15 days of storage while, there were significant different $(\mathrm{p}<0.05)$ among treatments at 21 days of storage period in count of $L b$. bulgaricus and $S$. thermophilus while there were significant differences $(p<0.05)$ among treatments in count of $B$. bifidum and total bacteria. The increase in counts of lactic acid bacteria may be due to the presence of some growth promoters and the decrease in bacterial count after 15 days of storage might be attributed to the developed acidity. These results are in agreement with those obtained by Ismail et al. (2014) and Tain et al. (2015) who recorded the highest viable count of $S$. thermophilus and $B$. bifidum when yoghurt fortified with $1.5 \%$ GMP, the increment was 5.68 times compared with control, but recorded GMP exerted little effect on the growth of Lb. bulgaricus.

Also Table 1 illustrated that, all yoghurt treatments as well as control yoghurt were completely free from yeasts and moulds at zero time, 3 , and 7 days of storage period whereas, yeasts and moulds were appeared after 15 days of storage in yoghurt fortified with $0.01 \%$ GMP (T1) and control (T0) while yeasts and moulds were not detected in yoghurt fortified with $0.1 \% \mathrm{CVOO}$ and there were no significant different $(\mathrm{p}<$ 0.05 ) among treatments and all yoghurt treatments as well as control were completely free from coliform. These results are in agreement with the findings obtained by Abbas et al. (2015).

\section{Chemical Analyses of Bio-Yoghurt}

Based on the results presented in Table 2, $\mathrm{pH}$ values of all yoghurt samples, generally decreased during storage period (21 days). This phenomenon was due to the growth of lactic acid bacteria and the production of lactic acid which was due to the especial synergistic effect between Lactobacilli spp and Streptococci spp. (Yousef et al., 2013). Also, there were slight differences and insignificant in $\mathrm{pH}$ values between control yoghurt and treated yoghurt during the storage period was observed. 
Table 1. Viable count of $L$ b. bulgaricus, S. thermophilus, B. bifidum, Total bacteria, Yeast and Mould and Coliform group of bio-yoghurt fortified with GMP and CVOO during storage for 21 days at $5^{\circ} \mathrm{C}$

\begin{tabular}{|c|c|c|c|c|}
\hline \multirow[t]{2}{*}{ Storage days } & \multicolumn{3}{|c|}{ Treatments } & \multirow[t]{2}{*}{ LSD $0.05 \%$} \\
\hline & T0 & T1 & $\mathbf{T 2}$ & \\
\hline \multicolumn{5}{|c|}{ Lb. bulgaricus $\log 10(\mathrm{cfu} / \mathrm{ml})$} \\
\hline $\mathbf{0}$ & $7.89^{\mathrm{b}} \pm 0.1$ & $9.13^{\mathrm{a}} \pm 0.1$ & $9.11^{\mathrm{a}} \pm 0.1$ & 0.18 \\
\hline 3 & $8.09^{b} \pm 0.1$ & $9.42^{\mathrm{a}} \pm 0.1$ & $9.36^{\mathrm{a}} \pm 0.1$ & 0.18 \\
\hline 7 & $9.39^{\mathrm{b}} \pm 0.1$ & $10.60^{\mathrm{a}} \pm 0.1$ & $10.53^{\mathrm{a}} \pm 0.1$ & 0.18 \\
\hline 15 & $9.48^{\mathrm{b}} \pm 0.1$ & $11.18^{\mathrm{a}} \pm 0.1$ & $11.14^{\mathrm{a}} \pm 0.1$ & 0.18 \\
\hline 21 & $9.23^{\mathrm{c}} \pm 0.1$ & $11.13^{\mathrm{a}} \pm 0.1$ & $11.05^{\mathrm{b}} \pm 0.1$ & 0.18 \\
\hline \multicolumn{5}{|c|}{ S. thermophilus $\log 10(\mathrm{cfu} / \mathrm{ml})$} \\
\hline $\mathbf{0}$ & $7.70^{\mathrm{b}} \pm 0.1$ & $9.05^{\mathrm{a}} \pm 0.1$ & $9.01^{\mathrm{a}} \pm 0.1$ & 0.18 \\
\hline 3 & $7.98^{b} \pm 0.1$ & $9.35^{\mathrm{a}} \pm 0.1$ & $9.30^{\mathrm{a}} \pm 0.1$ & 0.18 \\
\hline 7 & $9.30^{\mathrm{b}} \pm 0.1$ & $10.54^{\mathrm{a}} \pm 0.1$ & $10.48^{\mathrm{a}} \pm 0.1$ & 0.18 \\
\hline 15 & $9.43^{\mathrm{c}} \pm 0.1$ & $10.65^{\mathrm{a}} \pm 0.1$ & $10.54^{\mathrm{b}} \pm 0.1$ & 0.18 \\
\hline 21 & $9.24^{\mathrm{c}} \pm 0.1$ & $10.43^{\mathrm{a}} \pm 0.1$ & $10.36^{\mathrm{b}} \pm 0.1$ & 0.18 \\
\hline \multicolumn{5}{|c|}{ B. bifidum $\log 10(\mathrm{cfu} / \mathrm{ml})$} \\
\hline $\mathbf{0}$ & $7.74^{\mathrm{c}} \pm 0.1$ & $8.85^{\mathrm{a}} \pm 0.1$ & $8.76^{\mathrm{b}} \pm 0.1$ & 0.18 \\
\hline 3 & $7.93^{c} \pm 0.1$ & $9.34^{\mathrm{a}} \pm 0.1$ & $9.17^{\mathrm{b}} \pm 0.1$ & 0.18 \\
\hline 7 & $8.85^{\mathrm{c}} \pm 0.1$ & $9.86^{\mathrm{a}} \pm 0.1$ & $9.72^{b} \pm 0.1$ & 0.18 \\
\hline 15 & $9.36^{\mathrm{c}} \pm 0.1$ & $10.25^{\mathrm{a}} \pm 0.1$ & $10.19^{\mathrm{b}} \pm 0.1$ & 0.18 \\
\hline 21 & $8.87^{\mathrm{c}} \pm 0.1$ & $9.74^{\mathrm{a}} \pm 0.1$ & $9.63^{b} \pm 0.1$ & 0.18 \\
\hline \multicolumn{5}{|c|}{ Total bacterial count $(\mathbf{c f u} / \mathbf{m l})$} \\
\hline $\mathbf{0}$ & $7.86^{\mathrm{b}} \pm 0.1$ & $9.11^{\mathrm{a}} \pm 0.1$ & $9.08^{\mathrm{a}} \pm 0.1$ & 0.18 \\
\hline 3 & $8.00^{c} \pm 0.1$ & $9.40^{\mathrm{a}} \pm 0.1$ & $9.31^{b} \pm 0.1$ & 0.18 \\
\hline 7 & $9.38^{\mathrm{c}} \pm 0.1$ & $10.48^{a} \pm 0.1$ & $10.33^{\mathrm{b}} \pm 0.1$ & 0.18 \\
\hline 15 & $9.46^{\mathrm{b}} \pm 0.1$ & $11.10^{\mathrm{a}} \pm 0.1$ & $11.00^{\mathrm{a}} \pm 0.1$ & 0.18 \\
\hline 21 & $9.25^{\mathrm{c}} \pm 0.1$ & $11.01^{\mathrm{a}} \pm 0.1$ & $10.81^{\mathrm{b}} \pm 0.1$ & 0.18 \\
\hline \multicolumn{5}{|c|}{ Yeast and Mould $\log 10(\mathrm{cfu} / \mathrm{ml})$} \\
\hline $\mathbf{0}$ & ND & ND & ND & \\
\hline 3 & ND & ND & ND & \\
\hline 7 & ND & ND & ND & \\
\hline 15 & $1.30^{\mathrm{a}} \pm 0.1$ & $1.47^{\mathrm{a}} \pm 0.1$ & ND & 0.18 \\
\hline 21 & $2.00^{\mathrm{a}} \pm 0.1$ & $2.30^{\mathrm{a}} \pm 0.1$ & ND & 0.18 \\
\hline \multicolumn{5}{|c|}{ Coliform group $\log 10(\mathrm{cfu} / \mathrm{ml})$} \\
\hline $\mathbf{0}$ & ND & ND & ND & \\
\hline 3 & ND & ND & ND & \\
\hline 7 & ND & ND & ND & \\
\hline 15 & ND & ND & ND & \\
\hline 21 & ND & ND & ND & \\
\hline
\end{tabular}

T0: Control yoghurt + B.bifidum. $\quad$ T1: Yoghurt fortified with 0.01\% GMP + B.bifidum.

T2: Yoghurt fortified with $0.1 \%$ CVOO + B.bifidum.

Values are means $\pm \mathrm{SE}$

Data average of three replicates.

Means in the same row with different letters are significantly different $(p<0.05)$. 
Table 2. pH and Acidity values of bio-yoghurt fortified with GMP and CVOO during storage for 21 days at $5^{\circ} \mathrm{C}$

\begin{tabular}{cccccc}
\hline Parameter & Storage days & \multicolumn{4}{c}{ Treatments } \\
\hline $\mathbf{p H}$ & & $\mathbf{T 0}$ & $\mathbf{T 1}$ & $\mathbf{T 2}$ & LSD 0.05\% \\
\hline & $\mathbf{0}$ & $4.60^{\mathrm{a}} \pm 0.1$ & $4.58^{\mathrm{a}} \pm 0.1$ & $4.48^{\mathrm{a}} \pm 0.1$ & 0.18 \\
& $\mathbf{3}$ & $4.55^{\mathrm{a}} \pm 0.1$ & $4.50^{\mathrm{a}} \pm 0.1$ & $4.42^{\mathrm{a}} \pm 0.1$ & 0.18 \\
& $\mathbf{7}$ & $4.48^{\mathrm{a}} \pm 0.1$ & $4.41^{\mathrm{a}} \pm 0.1$ & $4.33^{\mathrm{a}} \pm 0.1$ & 0.18 \\
& $\mathbf{1 5}$ & $4.39^{\mathrm{a}} \pm 0.1$ & $4.35^{\mathrm{a}} \pm 0.1$ & $4.28^{\mathrm{a}} \pm 0.1$ & 0.18 \\
& $\mathbf{2 1}$ & $4.28^{\mathrm{a}} \pm 0.1$ & $4.23^{\mathrm{a}} \pm 0.1$ & $4.11^{\mathrm{a}} \pm 0.1$ & 0.18 \\
Acidity (\%) & & & & & \\
(Lactic acid) & $\mathbf{0}$ & $0.62^{\mathrm{a}} \pm 0.1$ & $0.67^{\mathrm{a}} \pm 0.1$ & $0.72^{\mathrm{a}} \pm 0.1$ & 0.18 \\
& $\mathbf{3}$ & $0.65^{\mathrm{a}} \pm 0.1$ & $0.70^{\mathrm{a}} \pm 0.1$ & $0.78^{\mathrm{a}} \pm 0.1$ & 0.18 \\
& $\mathbf{7}$ & $0.71^{\mathrm{a}} \pm 0.1$ & $0.76^{\mathrm{a}} \pm 0.1$ & $0.87^{\mathrm{a}} \pm 0.1$ & 0.18 \\
& $\mathbf{1 5}$ & $0.74^{\mathrm{a}} \pm 0.1$ & $0.81^{\mathrm{a}} \pm 0.1$ & $0.95^{\mathrm{a}} \pm 0.1$ & 0.18 \\
& $\mathbf{2 1}$ & $0.80^{\mathrm{a}} \pm 0.1$ & $0.86^{\mathrm{a}} \pm 0.1$ & $1.00^{\mathrm{a}} \pm 0.1$ & 0.18 \\
\hline
\end{tabular}

* see foot note Table 1

These results were coincided with the data obtained by Tain et al. (2015) and Abbas et al. (2015).

It is clear from the results presented in Table 3 that, total solids content (TS) was a significantly differed $(p<0.05)$ among treatments and TS increased in all treatments during cold storage with the lowest content in the control compared with treated yoghurts during the storage period. Yoghurt fortified with $0.1 \%$ CVOO (T2) had the highest TS content, while the lowest value was in control (T0) at zero time and during storage period. The increase in total solids content during storage period attributed to the loss of moisture (Tamime and Robinson, 1985). These results are similar to those obtained by Abbas et al. (2015) and Goldar et al. (2016).

Table 3 show the total protein content (TP) of bio-yoghurt fortified with GMP and CVOO. TP content of all treatments were significantly different $(\mathrm{p}<0.05)$ and gradually increased during storage whereas the value of control treatment was lower than the others over the storage period. Yoghurt fortified with $0.01 \%$ GMP (T1) had the highest TP content $(4.45 \%)$, while the lowest value obtained $(4.27 \%)$ was in control and T2 at zero time of storage, Similar trends were obtained throughout the rest of storage period up to 21 days. The increase in TP was probably due to the increase in total solid. Also, it was clear from this Table that water soluble nitrogen content (WSN\%) of all treatments was significantly different $(p<0.05)$ and gradually increased during storage, whereas the value of control treatment was lower than the others over the storage period and yoghurt fortified with $0.1 \%$ CVOO (T2) had the highest WSN content more than other treatments at zero time and during storage period. These results are similar to those obtained by Goldar et al. (2016) and Ismail et al. (2014). 
Table 3. Chemical analyses of bio-yoghurt fortified with GMP and CVOO during storage for 21 days at $5^{\circ} \mathrm{C}$

\begin{tabular}{|c|c|c|c|c|c|}
\hline \multirow[t]{2}{*}{ Parameter } & \multirow[t]{2}{*}{ Storage days } & \multicolumn{4}{|c|}{ Treatments } \\
\hline & & T0 & $\mathbf{T 1}$ & $\mathbf{T} 2$ & LSD $0.05 \%$ \\
\hline \multirow{5}{*}{$\begin{array}{c}\text { Total solids } \\
(\%)\end{array}$} & $\mathbf{0}$ & $13.15^{\mathrm{c}} \pm 0.1$ & $14.05^{\mathrm{b}} \pm 0.1$ & $14.47^{\mathrm{a}} \pm 0.1$ & 0.18 \\
\hline & 3 & $13.86^{\mathrm{c}} \pm 0.1$ & $14.66^{\mathrm{b}} \pm 0.1$ & $14.89^{\mathrm{a}} \pm 0.1$ & 0.18 \\
\hline & 7 & $14.05^{\mathrm{c}} \pm 0.1$ & $14.87 \pm 0.1$ & $15.12^{\mathrm{a}} \pm 0.1$ & 0.18 \\
\hline & 15 & $14.27^{\mathrm{c}} \pm 0.1$ & $15.06^{\mathrm{b}} \pm 0.1$ & $15.33^{\mathrm{a}} \pm 0.1$ & 0.18 \\
\hline & 21 & $14.50^{\mathrm{c}} \pm 0.1$ & $15.24^{\mathrm{b}} \pm 0.1$ & $15.56^{\mathrm{a}} \pm 0.1$ & 0.18 \\
\hline \multirow[t]{5}{*}{$\mathrm{TP}(\%)$} & $\mathbf{0}$ & $4.27^{\mathrm{b}} \pm 0.1$ & $4.45^{\mathrm{a}} \pm 0.1$ & $4.27^{\mathrm{b}} \pm 0.1$ & 0.18 \\
\hline & 3 & $4.36^{\mathrm{b}} \pm 0.1$ & $4.53^{\mathrm{a}} \pm 0.1$ & $4.38^{\mathrm{b}} \pm 0.1$ & 0.18 \\
\hline & 7 & $4.42^{b} \pm 0.1$ & $4.68^{\mathrm{a}} \pm 0.1$ & $4.43^{b} \pm 0.1$ & 0.18 \\
\hline & 15 & $4.51^{\mathrm{b}} \pm 0.1$ & $4.74^{\mathrm{a}} \pm 0.1$ & $4.52^{\mathrm{b}} \pm 0.1$ & 0.18 \\
\hline & 21 & $4.57^{\mathrm{b}} \pm 0.1$ & $4.83^{\mathrm{a}} \pm 0.1$ & $4.59^{\mathrm{a}} \pm 0.1$ & 0.18 \\
\hline \multirow[t]{5}{*}{ WSN (\%) } & $\mathbf{0}$ & $0.043^{\mathrm{b}} \pm 0.1$ & $0.054^{\mathrm{a}} \pm 0.1$ & $0.049^{\mathrm{a}} \pm 0.1$ & 0.18 \\
\hline & 3 & $0.048^{b} \pm 0.1$ & $0.055^{\mathrm{a}} \pm 0.1$ & $0.053^{\mathrm{a}} \pm 0.1$ & 0.18 \\
\hline & 7 & $0.054^{\mathrm{a}} \pm 0.1$ & $0.057^{\mathrm{a}} \pm 0.1$ & $0.057^{\mathrm{a}} \pm 0.1$ & 0.18 \\
\hline & 15 & $0.057^{\mathrm{a}} \pm 0.1$ & $0.060^{\mathrm{a}} \pm 0.1$ & $0.073^{\mathrm{a}} \pm 0.1$ & 0.18 \\
\hline & 21 & $0.059^{b} \pm 0.1$ & $0.064^{b} \pm 0.1$ & $0.086^{\mathrm{a}} \pm 0.1$ & 0.18 \\
\hline \multirow[t]{5}{*}{ Fat $(\%)$} & $\mathbf{0}$ & $3.4^{\mathrm{b}} \pm 0.1$ & $3.4^{\mathrm{b}} \pm 0.1$ & $3.7^{\mathrm{a}} \pm 0.1$ & 0.18 \\
\hline & 3 & $3.4^{\mathrm{b}} \pm 0.1$ & $3.5^{b} \pm 0.1$ & $3.8^{\mathrm{a}} \pm 0.1$ & 0.18 \\
\hline & 7 & $3.5^{\mathrm{b}} \pm 0.1$ & $3.5^{\mathrm{b}} \pm 0.1$ & $3.8^{\mathrm{a}} \pm 0.1$ & 0.18 \\
\hline & 15 & $3.6^{b} \pm 0.1$ & $3.6^{\mathrm{b}} \pm 0.1$ & $3.9^{\mathrm{a}} \pm 0.1$ & 0.18 \\
\hline & 21 & $3.7^{\mathrm{b}} \pm 0.1$ & $3.7^{\mathrm{b}} \pm 0.1$ & $4.0^{\mathrm{a}} \pm 0.1$ & 0.18 \\
\hline
\end{tabular}

*see foot note Table 1 
It was clear from this Table that fat $(\%)$ of all treatments was significantly different $(\mathrm{p}<0.05)$ and gradually increased during storage and fat content value was low in control treatment over the storage period compared to other treatments. Yoghurt fortified with $0.1 \%$ CVOO (T2) had the highest value $(3.7 \%)$, whereas the lowest of $3.4 \%$ was found in control and $\mathrm{T} 1$ at zero time, similar results were recorded during storage period. The obtained results are in agreement with those obtained by Ismail $\boldsymbol{e t}$ al. (2014) and Abbas et al. (2015).

Table 4 show syneresis of yoghurt fortified with GMP and CVOO, there is a significant different $(\mathrm{p}<0.05)$ among treatments, syneresis decreased during progress of storage period. The highest value of syneresis was observed in control (T0), while the lowest value was observed in yoghurt fortified with $0.01 \%$ GMP (T1) at zero time and during storage for 21 days at $5^{\circ} \mathrm{C}$. The decrease in syneresis might be due to increase the total solids content of yoghurt, especially the protein and fiber content had water holding capacity that absorbs the whey released leading to decrease syneresis (Al-Hamdani, 2016).

Charles and Carmen (2008) reported that the inclusion of the carbohydrate components reduced product syneresis and improved the texture and rheological properties of the supplemented yoghurt. These results are in agreement with those obtained by Ismail et al. (2014).

\section{Rheological Analyses}

Table 5 show the texture analysis of different samples of bio-yoghurt fortified with GMP and CVOO during storage period. It is clear from these results that all texture analysis (hardness,cohesiveness, gumminess and chewiness) except springiness increased during storage period for all treatments as follow:

\section{Hardness}

It was increased during storage period and there is a significant different $(p<0.05)$ among treatments. The highest values were obtained in yoghurt fortified with GMP (T1) while, the lowest values recorded in yoghurt fortified with CVOO (T2) at zero time and during storage period.

\section{Cohesiveness}

It was increased during storage period and there is a significant different $(\mathrm{p}<0.05)$ among treatments. The values of cohesiveness were relatively lower for yoghurt samples supplemented with additives than in plain yoghurt samples, this might be due to the strength of protein-protein interaction bonds in control yoghurt rather than in the mixture of milk and additives which weakened this phenomenon (El Din et al., 2014).

\section{Springiness}

It was clear from springiness result that, there is a significant different $(p<0.05)$ among treatments and its values decreased for all treatments during storage period. This might be due to the continuous breakdown of protein matrix and its strength, the latter being dependent on some factors such as moisture and fat content (Lawrence et al., 1983).

\section{Gumminess, Chewiness}

It was clear that, there is a significant different $(p<0.05)$ among treatments and the values of Gumminess and chewiness increased for all treatments during storage period. Yoghurt fortified with food additives had higher values of chewiness more than control during storage, this might be due to the lower moisture, the moisture acts as a plasticizer in the protein matrix, by making it less elastic and more susceptible to fracture upon compression (Folkertsma and Fox, 1992).

\section{Organoleptic Properties}

Results in Table 6 show the organoleptic properties of bio-yoghurt fortified with GMP and CVOO. Organoleptic properties are important parameters to determine the quality and shelf life of yoghurt. The total 
Table 4. Syneresis of bio-yoghurt fortified with GMP and CVOO during storage for 21 days at $5^{\circ} \mathrm{C}$

\begin{tabular}{|c|c|c|c|c|}
\hline \multirow[t]{3}{*}{ Storage days } & \multicolumn{4}{|c|}{ Syneresis (ml whey/50g yoghurt) } \\
\hline & \multicolumn{4}{|c|}{ Treatments } \\
\hline & T0 & $\mathbf{T 1}$ & T4 & LSD $0.05 \%$ \\
\hline $\mathbf{0}$ & $11.0^{\mathrm{a}} \pm 0.1$ & $8.4^{c} \pm 0.1$ & $10.3^{\mathrm{b}} \pm 0.1$ & 0.18 \\
\hline 3 & $10.6^{\mathrm{a}} \pm 0.1$ & $8.0^{c} \pm 0.1$ & $9.7^{\mathrm{b}} \pm 0.1$ & 0.18 \\
\hline 7 & $9.0^{\mathrm{a}} \pm 0.1$ & $7.2^{c} \pm 0.1$ & $8.0^{\mathrm{b}} \pm 0.1$ & 0.18 \\
\hline 15 & $8.6^{\mathrm{a}} \pm 0.1$ & $6.4^{\mathrm{c}} \pm 0.1$ & $7.5^{b} \pm 0.1$ & 0.18 \\
\hline 21 & $8.0^{\mathrm{a}} \pm 0.1$ & $5.8^{\mathrm{c}} \pm 0.1$ & $7.0^{\mathrm{b}} \pm 0.1$ & 0.18 \\
\hline
\end{tabular}

* see foot note Table 1

Table 5. Texture analysis performed for bio-yoghurt fortified with GMP and CVOO during storage for 21 days at $5^{\circ} \mathrm{C}$

\begin{tabular}{|c|c|c|c|c|c|}
\hline \multirow{2}{*}{ Analysis } & \multirow{2}{*}{$\begin{array}{l}\text { Storage } \\
\text { days }\end{array}$} & \multicolumn{4}{|c|}{ Treatments } \\
\hline & & T0 & T1 & $\mathbf{T 2}$ & LSD $0.05 \%$ \\
\hline $\begin{array}{l}\text { 1- Hardness } \\
\text { (N) }\end{array}$ & $\begin{array}{c}0 \\
7 \\
15 \\
21\end{array}$ & $\begin{array}{l}1.8^{\mathrm{b}} \pm 0.1 \\
1.9^{\mathrm{b}} \pm 0.1 \\
2.8^{\mathrm{b}} \pm 0.1 \\
3.6^{\mathrm{b}} \pm 0.1\end{array}$ & $\begin{array}{c}2.8^{\mathrm{a}} \pm 0.1 \\
3.1^{\mathrm{a}} \pm 0.1 \\
3.7^{\mathrm{a}} \pm 0.1 \\
4.3^{\mathrm{a}} \pm 0.1\end{array}$ & $\begin{array}{l}1.3^{c} \pm 0.1 \\
1.6^{c} \pm 0.1 \\
2.4^{c} \pm 0.1 \\
2.5^{c} \pm 0.1\end{array}$ & 0.18 \\
\hline $\begin{array}{c}\text { 2- Cohesiveness } \\
\text { (N) }\end{array}$ & $\begin{array}{c}0 \\
7 \\
15 \\
21\end{array}$ & $\begin{array}{l}0.67^{\mathrm{a}} \pm 0.1 \\
0.71^{\mathrm{a}} \pm 0.1 \\
0.79^{\mathrm{a}} \pm 0.1 \\
1.03^{\mathrm{a}} \pm 0.1\end{array}$ & $\begin{array}{l}0.49^{\mathrm{b}} \pm 0.1 \\
0.66^{\mathrm{a}} \pm 0.1 \\
0.68^{\mathrm{b}} \pm 0.1 \\
0.79^{\mathrm{b}} \pm 0.1\end{array}$ & $\begin{array}{c}0.50^{\mathrm{b}} \pm 0.1 \\
0.59^{\mathrm{a}} \pm 0.1 \\
0.72^{\mathrm{b}} \pm 0.1 \\
0.77^{\mathrm{b}} \pm 0.1\end{array}$ & 0.18 \\
\hline $\begin{array}{l}\text { 3- Springiness } \\
\text { (mm) }\end{array}$ & $\begin{array}{c}0 \\
7 \\
15 \\
21\end{array}$ & $\begin{array}{l}8.20^{\mathrm{a}} \pm 0.1 \\
8.17^{\mathrm{a}} \pm 0.1 \\
8.16^{\mathrm{a}} \pm 0.1 \\
6,89^{\mathrm{a}} \pm 0.1\end{array}$ & $\begin{array}{l}8.20^{\mathrm{a}} \pm 0.1 \\
7.41^{\mathrm{b}} \pm 0.1 \\
7.38^{\mathrm{b}} \pm 0.1 \\
7.01^{\mathrm{a}} \pm 0.1\end{array}$ & $\begin{array}{l}7.75^{\mathrm{b}} \pm 0.1 \\
7.59^{\mathrm{b}} \pm 0.1 \\
7.19^{\mathrm{c}} \pm 0.1 \\
6.98^{\mathrm{a}} \pm 0.1\end{array}$ & 0.18 \\
\hline $\begin{array}{l}\text { 4- Gumminess } \\
\text { (N) }\end{array}$ & $\begin{array}{c}0 \\
7 \\
15 \\
21\end{array}$ & $\begin{array}{c}0.9^{\mathrm{c}} \pm 0.1 \\
1.3^{\mathrm{b}} \pm 0.1 \\
2.3^{\mathrm{ab}} \pm 0.1 \\
2.4^{\mathrm{b}} \pm 0.1\end{array}$ & $\begin{array}{l}1.5^{\mathrm{a}} \pm 0.1 \\
1.9^{\mathrm{a}} \pm 0.1 \\
2.5^{\mathrm{a}} \pm 0.1 \\
3.4^{\mathrm{a}} \pm 0.1\end{array}$ & $\begin{array}{l}1.1^{\mathrm{b}} \pm 0.1 \\
1.3^{\mathrm{b}} \pm 0.1 \\
1.4^{\mathrm{b}} \pm 0.1 \\
1.7^{\mathrm{c}} \pm 0.1\end{array}$ & 0.18 \\
\hline $\begin{array}{c}\text { 5- Chewiness } \\
(\mathrm{mJ})\end{array}$ & $\begin{array}{c}0 \\
7 \\
15 \\
21\end{array}$ & $\begin{array}{c}7.75^{\mathrm{c}} \pm 0.1 \\
10.50^{\mathrm{b}} \pm 0.1 \\
16.51^{\mathrm{b}} \pm 0.1 \\
18.74^{\mathrm{b}} \pm 0.1\end{array}$ & $\begin{array}{l}11.39^{\mathrm{a}} \pm 0.1 \\
13.44^{\mathrm{a}} \pm 0.1 \\
20.23^{\mathrm{a}} \pm 0.1 \\
25.05^{\mathrm{a}} \pm 0.1\end{array}$ & $\begin{array}{c}7.89^{b} \pm 0.1 \\
9.00^{c} \pm 0.1 \\
0.48^{c} \pm 0.1 \\
13.31^{c} \pm 0.1\end{array}$ & 0.18 \\
\hline
\end{tabular}


Table 6. Organoleptic properties of bio-yoghurt fortified with GMP and CVOO during storage for 21 days at $5^{\circ} \mathrm{C}$

\begin{tabular}{|c|c|c|c|c|c|}
\hline \multirow[t]{2}{*}{ Treatments } & \multirow{2}{*}{$\begin{array}{c}\text { Storage } \\
\text { days }\end{array}$} & \multicolumn{4}{|c|}{ Sensory parameter } \\
\hline & & $\begin{array}{c}\text { Appearance } \\
\text { (5) }\end{array}$ & $\begin{array}{l}\text { Body and texture } \\
\text { (5) }\end{array}$ & $\begin{array}{c}\text { Flavour } \\
\text { (10) }\end{array}$ & $\begin{array}{c}\text { Total acceptance } \\
\text { (20) }\end{array}$ \\
\hline \multirow[t]{5}{*}{ T0 } & $\mathbf{0}$ & $4.9^{\mathrm{a}} \pm 0.1$ & $4.5^{\mathrm{b}} \pm 0.1$ & $8.5^{\mathrm{b}} \pm 0.1$ & $17.9^{\mathrm{b}} \pm 0.1$ \\
\hline & 3 & $4.9^{\mathrm{a}} \pm 0.1$ & $4.5^{\mathrm{b}} \pm 0.1$ & $8.5^{\mathrm{b}} \pm 0.1$ & $17.9^{b} \pm 0.1$ \\
\hline & 7 & $4.8^{\mathrm{a}} \pm 0.1$ & $4.3^{\mathrm{b}} \pm 0.1$ & $8.0^{b} \pm 0.1$ & $17.1^{\mathrm{b}} \pm 0.1$ \\
\hline & 15 & $4.7^{\mathrm{a}} \pm 0.1$ & $4.0^{\mathrm{b}} \pm 0.1$ & $7.5^{\mathrm{b}} \pm 0.1$ & $16.2^{\mathrm{b}} \pm 0.1$ \\
\hline & 21 & $4.5^{\mathrm{a}} \pm 0.1$ & $3.7^{b} \pm 0.1$ & $7.0^{\mathrm{b}} \pm 0.1$ & $15.2^{\mathrm{b}} \pm 0.1$ \\
\hline \multirow[t]{5}{*}{$\mathbf{T 1}$} & $\mathbf{0}$ & $4.8^{\mathrm{ab}} \pm 0.1$ & $4.7^{\mathrm{a}} \pm 0.1$ & $9.5^{\mathrm{a}} \pm 0.1$ & $19.0^{\mathrm{a}} \pm 0.1$ \\
\hline & 3 & $4.8^{\mathrm{ab}} \pm 0.1$ & $4.7^{\mathrm{a}} \pm 0.1$ & $9.5^{\mathrm{a}} \pm 0.1$ & $19.0^{\mathrm{a}} \pm 0.1$ \\
\hline & 7 & $4.7^{\mathrm{ab}} \pm 0.1$ & $4.5^{\mathrm{a}} \pm 0.1$ & $9.2^{\mathrm{a}} \pm 0.1$ & $18.4^{\mathrm{a}} \pm 0.1$ \\
\hline & 15 & $4.5^{\mathrm{b}} \pm 0.1$ & $4.3^{\mathrm{a}} \pm 0.1$ & $8.7^{\mathrm{a}} \pm 0.1$ & $17.5^{\mathrm{a}} \pm 0.1$ \\
\hline & 21 & $4.2^{\mathrm{b}} \pm 0.1$ & $4.0^{\mathrm{a}} \pm 0.1$ & $8.5^{\mathrm{a}} \pm 0.1$ & $16.7^{\mathrm{a}} \pm 0.1$ \\
\hline \multirow[t]{5}{*}{$\mathbf{T 2}$} & $\mathbf{0}$ & $4.5^{\mathrm{b}} \pm 0.1$ & $4.0^{c} \pm 0.1$ & $8.0^{c} \pm 0.1$ & $16.5^{\mathrm{c}} \pm 0.1$ \\
\hline & 3 & $4.5^{\mathrm{b}} \pm 0.1$ & $4.0^{c} \pm 0.1$ & $8.0^{c} \pm 0.1$ & $16.5^{\mathrm{c}} \pm 0.1$ \\
\hline & 7 & $4.0^{\mathrm{b}} \pm 0.1$ & $3.7^{c} \pm 0.1$ & $7.5^{c} \pm 0.1$ & $15.2^{c} \pm 0.1$ \\
\hline & 15 & $3.5^{\mathrm{c}} \pm 0.1$ & $3.5^{\mathrm{c}} \pm 0.1$ & $7.0^{\mathrm{c}} \pm 0.1$ & $14.0^{\mathrm{c}} \pm 0.1$ \\
\hline & 21 & $3.0^{\mathrm{c}} \pm 0.1$ & $3.0^{\mathrm{c}} \pm 0.1$ & $6.5^{c} \pm 0.1$ & $12.5^{c} \pm 0.1$ \\
\hline LSD $0.05 \%$ & & 0.18 & 0.18 & 0.18 & 0.18 \\
\hline
\end{tabular}

scores of sensory evaluations of all treatments gradually decreased during storage, this might be due to the increase in the acidity, which affects the rheological properties (Ibrahim et al., 2003). Meanwhile, Salvador and Fiszman (2004) who reported decrease in the sensory score and general acceptability during the storage period.
Appearance indicated that, there is a significant different $(\mathrm{p}<0.05)$ among treatments, control yoghurt had the highest values, while the lowest values were in yoghurt fortified with CVOO (T2) at zero time. Similar results were obtained at 3 days of storage, and the values gradually decreased until the end of cold storage for all treatments. 
Body and texture indicated that there is a significant different $(\mathrm{p}<0.05)$ among treatments and treatment of yoghurt fortified with GMP (T1) had the highest values while the lowest values were in yoghurt fortified with CVOO at zero time. Similar results were obtained at 3 days of storage, and the values gradually decreased until the end of cold storage for all treatments.

The highest score of flavour was detected in the yoghurt fortified with GMP (T1), while the lowest value was in yoghurt fortified with CVOO (T2) and there is a significant different $(\mathrm{p}<0.05)$ among treatments. Similar results were obtained at 3 days of storage, and the values gradually decreased until the end of cold storage for all treatments.

Yoghurt fortified with GMP (T1) had the highest total acceptance, while the lowest total acceptance was in yoghurt fortified with CVOO (T2) during storage for 21 days at $5^{\circ} \mathrm{C}$ and there is a significant different $(\mathrm{p}$ $<0.05$ ) among treatments.

These results are in agreement with those obtained by Ismail et al., (2014).

\section{The Final Results of this Study}

The addition of $0.01 \%$ glycomacropeptide, $0.1 \%$ crude virgin olive oil, respectively to yoghurt and also add B. bifidum to yoghurt starter culture, which leads to improving the vitality of these strains during cold storage until reach the consumer in the recommended live numbers to show their desired effects, and save the product from spoilage during the storage period due to its inhibitory effect of yeasts, moulds and other bacteria causing food spoilage, as well as improving the rheological properties and the acceptability of yoghurt during storage period up to 21 days at $5{ }^{\circ} \mathrm{C}$.

\section{REFERENCES}

Abbas, H.M.; Hassan, F.A.M.; Kassem, J.M.; Rasmy, N.M.; El-Kaluobi, M.H. and El-Okaby, M.F. (2015). Preparation of cheese yoghurt using extracted high virgin olive oil. Int. J. Dairy Sci., 10 (6): 288-296.

Abd El-Salam, M.H.; El-Shibiniy, S.; Mahfuz, M.B.; El-Dein, H.F.; El-Atriby, H. and Antila, V. (1991). Preparation of whey protein concentrate from salted whey and its use in yoghurt. J. Dairy Res., 58: 503-510.

Al-Hamdani, H.M.S. (2016). Effect of Supplementation of yoghurt with Syrup of date palm on Quality Properties Products. Advances in life Sci. and Technol., 41: 2224-7181.

Alizadeh, A. and Ehsani, M.R. (2008). Probiotic survival in yoghurt made from ultrafiltered skim milk during refrigeration storage. Res. J. Biol. Sci., 3: 1163-1165.

\section{American Public Health Association} (1992). Standard Method for the Examination of Dairy Products. $14^{\text {th }} \mathrm{Ed}$. Washington, USA.

AOAC (2016). Association of Official Analytical Chemists. Official Methods of Analysis. $17^{\text {th }}$ Ed., Gaitherburg, M D, USA.

Brody, E.P. (2000). Biological activities of bovine glycomacropeptide. Br. J. Nutr., 84: 39-46.

Charles, S. and Carmen, M. (2008). Carbohydrate-based fat replaceers in the modification of the rheological, textural and sensory quality of yoghurt: comparative study of the utilization of barley beta-glucan, guar gum and insulin. Intr. J. Food Sci. and Technol., 43: 824-833.

Dave, R.I. and Shah, N.P. (1996). Evaluation of media for selective enumeration of Streptococcus thermopiles, Lactobacillus delbrueckii subsp. Bulgaricus, Lactobacillus acidophilus and bifidobacteria. J. Dairy Sci., 79: 1529. 
De Man, J.C.; Rogosa, M. and Sharp, M. E. (1960). A medium for the cultivation of lactobacilli. J. Appl. Bacteriol., 23: 130-136.

El Din, H.M.F.; Mohamed, S.S. and ElMessery, T.M. (2014). Role of the functional food (pomegranate-yoghourt) as hepatoprotective effect on liver injured rats. Int. J. Curr. Microbiol. App. Sci., 3 (8) 185-196.

Farrell, H.M.Jr.; Jimenez-Flores, R.; Bleck, G.T.; Brown, E. M.; Butler, J. E.; Creamer, L.K.; Hicks, C.L., Hollar, C.M.; Ng-Kwai-Hang, K.F. and Swaisgood, H.E. (2004). Nomenclature of the proteins of cows' milk-Sixth revision. J. Dairy Sci., 87, 1641-1674.

Folkertsma, B. and Fox, P.F. (1992). Use of the Cd-ninhydrin reagent to assess proteolysis in cheese during ripening. $\mathrm{J}$. Dairy Res., 59:217.

Frazier, W.C. and Foster, E.M. (1961). Laboratory Manual for Dairy Microbiology. Burgoss publishing Co. USA.

Gandul-Rojas, B.; Cepero, M.R.L. and Minguez-Mosquera, M.I. (2000). Use of chlorophyll and carotenoid pigment composition to determine authenticity of virgin olive oil. J. Ame. Oil Chem. Soc., 77: 853-858.

Goldar, P.; Givianarad, M.H. and Shams, A. (2016). Effect of ultrafiltered milk permeate and non-dairy creamer powder concentration on low phenylalanine yoghurt's physicochemical properties during storage. J. Food Sci. Technol., 53(7): 3053-3059.

Gundogdu, E.; Çakmakçi, S. and Dagdemir, E. (2009). The effect of garlic (Allium sativum L.) on some quality properties and shelf-life of set and stirred yoghurt. Turkish J. Vet. and Anim. Sci., (33): 27-35.
Harrigan, W.F. and Mcconce, M.E. (1966). Laboratory Methods in Microbiology. Academic press London and New York.

Ibrahim, G.A.; Kobeasy, M.I.; Mehanna, N.Sh. and Gad El-Rab, D.A. (2003). Production of novel types of functional fermented milk products. Egypt. J. Nutr., XVIII (2): 1-32.

International Dairy Federation (1991). Rheological and fracture properties of cheese. brussels, belgium: International Dairy Federation; Bull. IDF No. 268.

Ismail, M.M.; El-Shazly, A.K. and Eid, M.Z. (2014). Effect of supplementation with olive oil on some properties of bioyoghurt. The Asia J. Appl. Microbiol., 1(4): 66-77.

Krusch, U.; Neve, H.; Luschei, B. and Teuber, M. (1987). Characterization of virulent bactreophages of Streptococcus thermophilus by host specificity and electron microscopy. Kieler Milschwirtschaftl. Forsch. Ber., 39:155167.

Lawrence, R.C.; Gills, J. and Creamer, L.K. (1983). The relationship between cheese texture and flavour. New Zeland J. Dairy Sci. Technol., 67:175.

Marshall, R.T. (1992). Standard Methods for Examination of Dairy Products, $16^{\text {th }}$ Ed. Ame. Public Health Assoc. Washington, D.C.

Marshall, K. (2004). Therapeutic applications of whey protein. Altern. Med. Rev., 9, 136-156.

Ney, D.M.; Gleason, S.T. and Van Calcar S.C. (2009). Nutritional management of PKU with glycomacropeptide from cheese whey. J. Inherit. Metab. Dis., 32: 32-39.

Ocakoglu, D.; Tokatli, F.; Ozen, B. and Korel, F. (2009). Distribution of simple phenols, phenolic acids and flavonoids in Turkish monovarietal extra virgin 
olive oils for two harvest years. Food Chem., 113: 401-410.

Saarela, M.; Lahteenmaki, L.; Crittenden, R.; Salminen, S. and MattilaSandholm, T. (2002). Gut bacteria and health foods-the European perspective. Int. J. Food Microbiol., 78: 99-117.

Sahan, N.; Yasar, K. and Hayaloglu, A. A. (2008). Physical, chemical and flavor quality of non-fat yoghurt as affected by a $\beta$-glucan hydrocolloidal composite during storage. Food Hydrocolloid, 22, 1291:1297.

Salvador, A. and Fiszman, S.M. (2004). Textural and sensory characteristics of whole and skimmed flavored set-type yoghurt during long storage. J. Dairy Sci., 87:4033.

Sera, M.; Trujillo, JA.; Guamis, B. and Ferragut, V. (2009). Flavour profiles and survival of starter cultures of yoghurt produced from high-pressure homogenized milk. Int. Dairy J., 19: 100-106.

Steel, R.; Torrie, J. and Dickey, D. (1997). Principles and Procedures of Statistics: A Biometrical Approach, $3^{\text {rd }}$ Ed., McGraw-Hill, New York, NY.

Tain, Q.; Wang, T.T.; Tang, X.; Hang, M.Z.; Leng, X.J. and Mao, X.Y. (2015). Developing a potential prebiotic of yoghurt: growth of Bifidobacterium and yoghurt cultures with addition of glycomacropeptide hydrolysate. Int. J. Food Sci. and Technol., 50: 120-127.

Tamime, A.Y. and Robinson, R.K. (1985). Yoghurt Scinces and Technology. I, T Ed. Weaton and Co. Ltd., England.

Tamime, A.Y. and Robinson, R.K. (1999). Yoghurt. Science and Technology. London, UK: Wood head Publishing.

Vinderola, C.G. and Reinheimer, J.A. (2000). Enumeration of Lactobacilii casei in the presence of L. acidophilus, bifidobacteria and lactic starter bacteria in fermented dairy products. Int. Dairy J., 10: 271- 275.

Wani, T.A.; Masoodi, F.; Gani, A.; Baba, W.N.; Rahmanian, N. and Wani, I.A. (2018). Olive oil and its principal bioactive compound: Hydroxytyrosol-A review of the recent literature. Trends in Food Sci. and Technol., 77: 77-90.

Yousef, M.; Nateghi, L. and Azadi, E. (2013). Effect of different concentration of fruit additives on some physicochemical properties of yoghurt during storage. Ann. Biol. Res., 4 (4): 244-249. 


$$
\text { الملخص العربى }
$$

\section{تأثير الجليكوماكرويتيد وزيث الزيتون الخام البكر على خصائص الزبادي الحيوي}

علا فتحى السيد1، هويدا عبدالله الشاذلى 2، حسن عبدالمنعم الدمرداش11، ممدوح مصطفى كمال متولى 1

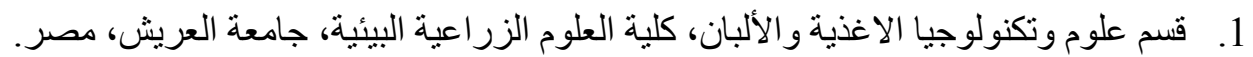

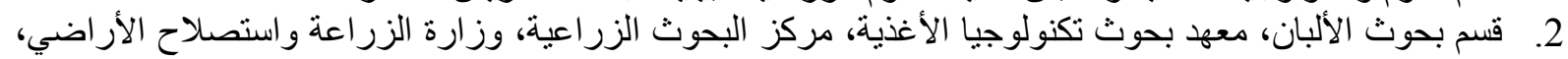

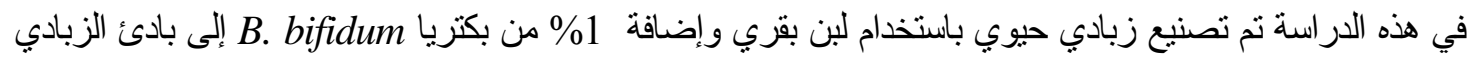

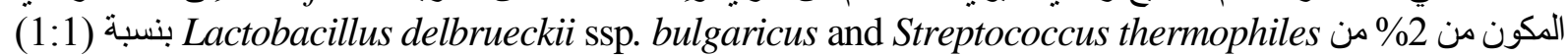

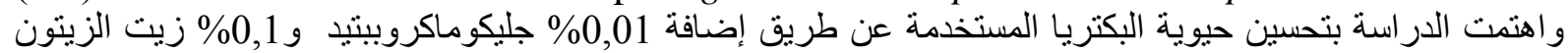

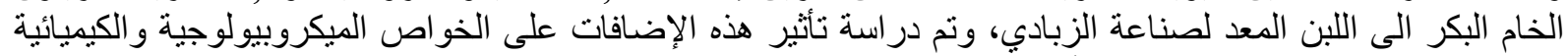

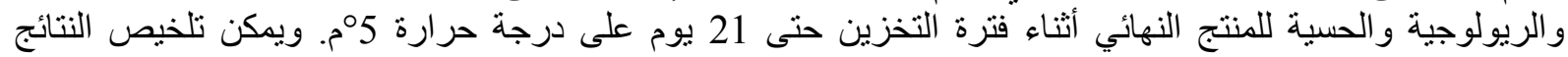

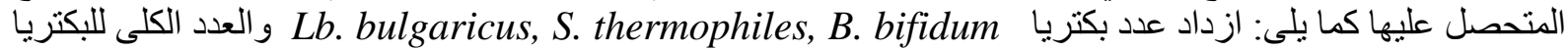

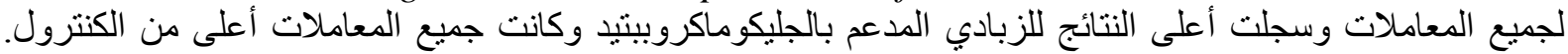

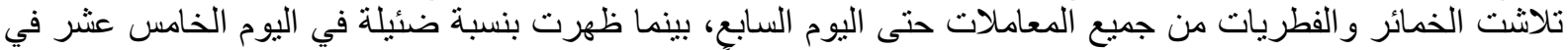

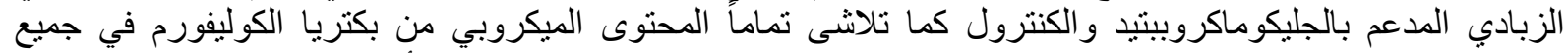

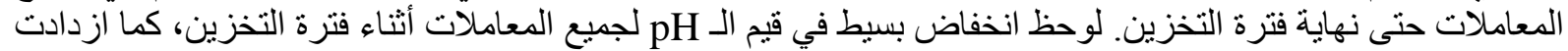

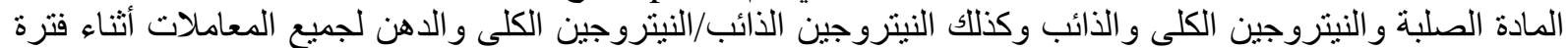

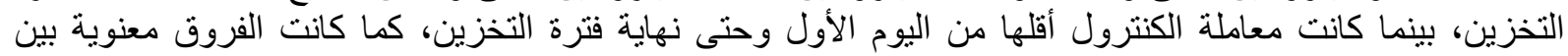

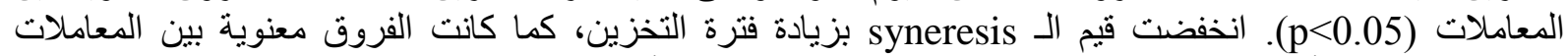

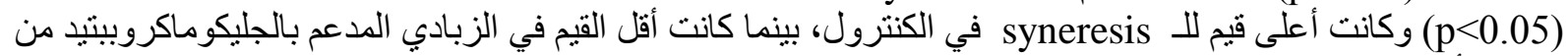

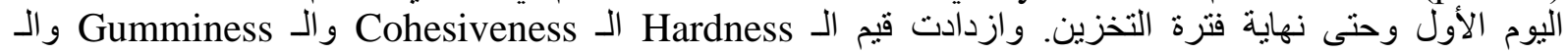
Chewiness

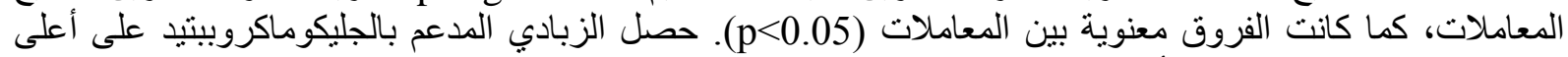

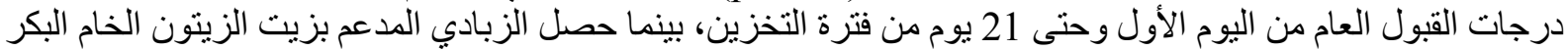
على أقل درجات القبول العام عن باقي المعاملات خلال فترة التخزين، كما كانت الفروق معنوية بين المعاملات

الكلمات الاسترشادية: زبادي، Bifidum، جليكوماكروبيتيد، زيت الزيتون.

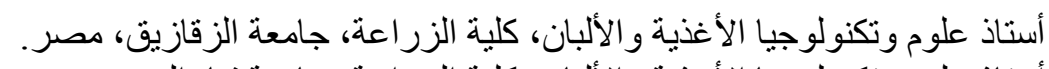
أستاذ علوم وتكنولوجيا الأغذية والألبان، كلية الزر البانة كلية، الزراعة، جامعة قناة السويس، مصر .

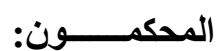

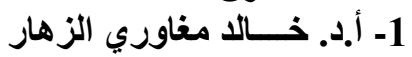

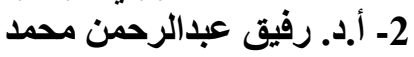


